\title{
KARAKTERISTIK MOTIF SULAMAN SELENDANG KOTO GADANG SUMATERA BARAT
}

\author{
Hendra $^{1 *}$, Yuni Kartika Sari ${ }^{* *}$ \\ Program Studi Kriya Seni Fakultas Seni Rupa dan Desain \\ Institut Seni Indonesia Padangpanjang \\ Jl. Bahder Johan, Guguak Malintang, Padangpanjang, Kota Padangpanjang, Kode Pos 27126 \\ Sumatera Barat. Indonesia \\ Email:doankhendra7@gmail.com, kartikasari96@gmail.com
}

\begin{abstract}
Abstrak
Penelitian ini bertujuan untuk mengetahui karakteristik bentuk dan struktur motif yang diterapkan pada sulaman selendang Koto Gadang. Motif suji caia yang diterapkan pada Sulaman Koto Gadang memiliki karakteristik yang membedakannya dengan sulaman dari daerah lain.Penelitian ini menggunakan metode kualitatif dengan pendekatan teori bentuk dan struktur seni rupa. Pengumpulan data dilakukan melalui studi pustaka, observasi, wawancara, dan dokumentasi.Motif yang diterapkan pada selendang berupa motif flora dan fauna. Menggunakan teori penyusunan unsur seni rupa, sehingga ciri khas motif terlihat dari bentuk motif dan struktuf motif yang seimbang. Motif khas dari selendang Koto Gadang berupa motif flora yang bernama bunga Botan dan Krisan. Peletakkan bunga pada selendang berbeda dengan daerah lain yang biasanya menggunakan formal balance mirror atau seperti kaca, serta penyusunan bunga dari kecil ke bunga besar.
\end{abstract}

Kata Kunci: sulaman selendang, motif, karakteristik.

\begin{abstract}
Block printi This study aims to determine the characteristics of the motifs applied to the Koto Gadang shawl. Motive of "suji caia" that applied to Koto Gadang embrodery has specified characteristic that make it different from another palce shawl. This study uses a qualitative method with a form and structure theory approach to art. Data collection was carried out through literature study, observation, interview, anh documentation.The motifs applied to the shawl are flora and fauna motifs. Using the theory of arranging elements of fine art, so that the characteristic of the motif can be seen from the shape of the motif and the structure of the motif that is balanced. The distinctive motif of the Koto Gadang shawl is a floral motif called Botan and Chrysanthemum. The placement of flowers on the shawl is different from other areas which usually use a formal balance mirror or like glass, as well as well as the arrangement of flowers from small to large flowers.
\end{abstract}

Keywords: shawl embroidered, motif, characteristics.

\section{PENDAHULUAN}

Sulaman merupakan salah satu hasil karya budaya masyarakat Sumatera Barat yang sudah dikenal luas baik dalam maupun luar negeri. Bermacam-macam bentuk dari sulaman sebagai kreativitas budaya masyarakat dapat ditemui di Sumatera Barat seperti, Sulaman Nareh Pariaman, sulaman benang emas Pasaman Barat, sulaman bayang Pesisir Selatan, dan sulaman suji caie Koto Gadang.

Sulaman di setiap daerah memiliki karakter yang berbeda terutama bila ditinjau dari bentuk dan penerapan motifnya. Karakter atau ciri khas sulaman di setiap daerah merupakan jati diri atau pembeda dengan objek lainnya yang bisa dilihat secara visual. Sulam Suji caie, merupakan salah satu teknik sulam yang sering digunakan pada selendang. Teknik ini juga menjadi ciri khas sulaman di Koto Gadang, karena menghasilkan efek tiga dimensi dari pencairan warna benang. Kata Caie yang disebutkan berarti mencairkan warna, karena penggunaan benang lebih dari satu warna yang dijahitkan dengan ukuran panjang pendek. Menurut Sita \& Mity J.Juni (2011: 24) bahwa, Benang yang digunakan biasanya sutra atau satin yang mempunyai lima sampai dengan enam tingkatan warna. Benang yang digunakan juga berbeda dan teksturnya mengkilat, sehingga akan menimbulkan bayangan seperti tiga dimensi pada motif.

Penambah benang emas juga hanya pada motif batang dan daun, kecuali pada sulaman kapalo samek. Sulaman kapalo samek hanya menggunakan tiga gradasi warna dan dikelilingi dengan benang emas atau perak. Kehalusan dan kerapian sulaman pada selendang 
Gorga : Jurnal Seni Rupa

Volume 10 Nomor 02 Juli-Desember 2021

p-ISSN: 2301-5942 | e-ISSN: 2580-2380

Koto Gadang ini akan terlihat berbeda, karena pada bagian depan dan belakangnya tidak akan terlihat sisa benang. Mereka menggunak;an teknik sisip benang pada sela-sela sulaman. Kepadatan sulaman juga dikarenakan bahan selendang dibentangkan di atas pamedangan yang terbuat dari kayu seperti meja.

pentingnya kerajinan sulaman di Koto Gadang sesuai dengan mamangan atau pepatah "Awak sakik pusako manolong, awak sanang pusako ditolong " artinya pusaka bukan hanya sebagai benda atau harta tetapi juga sebagai adat, adab serta keterampilan yang merupakan warisan dari nenek moyang kita (Canang, 1994: 20). Peran pentingnya sulaman dan selendang dalam kehidupan adat Minangkabau dikenal dengan "Upacara sepanjang kehidupan", dan selendang sulam selau menjadi pelengkap di setiap upacara adat seperti; kelahiran, turun mandi, karek pusek, sunat rasul, khatam kaji, pinang-maminang, baralek nikah kawin, manjalang mintuo, batagak gala, baipa bisan, bahkan upacara kematian (Garang, 2019:17). selendang sulam Koto Gadang ada dua jenis yaitu Selendang Gadang dan Selendang Ringan. Masing-masing selendang mempunyai struktur dan bentuk motif yang berbeda, baik dari jumlah motif, ukuran motif, struktur motif, dan warna pada selendang.

Motif sulaman Koto Gadang pada umumnya berupa bunga, sulur, daun dan hewan. Menurut data di lapangan motif yang berkembang dipengaruh beberapa kebudayaan, diantaranya pengaruh Cina pada motif bunga, seperti bunga Botan, Krisan, pengaruh kebudayaan Arab yang identik dengan motif suluran. Pengaruh Kebudayaan Cina juga mempengaruhi jumlah dan susunan motif yang diterapkan, serta menentukan warna dasar selendang dan pengguna selendang. Selendang Koto Gadang hanya digunakan oleh orang yang sudah menikah, untuk anak gadis menggunakan kain batik. Sulaman motif penuh dengan akan digunakan oleh wanita yang baru menikah dan motif sedikit oleh wanita yang sudah lebih dewasa. Selendang Koto Gadang biasanya terdiri dari warna gelap dan terang tergantung usia pengguna seperti merah, kuning, hijau tua, ungu dan biru. Oleh karena itu penelitian ini lebih menekankan secara spesifik pada karakteristik Koto Gadang. Meskipun sudah banyak yang meneliti tentang selendang sulaman Koto Gadang, namun belum ada yang membahas secara khusus dari bentuk motif selendang itu sendiri terutama mengeni struktur motif sulam selendang Koto Gadang.

\section{KAJIAN TEORI}

Untuk memahami permasalahan yang berhubungan dengan motif-motif yang diterapkan pada selendang
Koto Gadang, dan akan menggunakan beberapa pendekatan untuk menjelaskan dan menganalisis sumber dari temuan.

\section{Karakteristik}

Juwita (2019: 5) mengatakan bahwa: karakteristik adalah suatu yang khas yang terdapat pada objek. Warsono dalam Rahmadona mengungkapkan karakteristik tidak lepas dari budaya, budaya sebagai kumpulan nilai dan norma di bentuk dan disepakati oleh masyarakat sehingga menjadi suatu ciri khas. Jadi karakteristik sulaman Koto Gadang adalah ciri khas dari sulaman tersebut yang membedakannya dengan sulaman dari daerah yang lain.

\section{Motif}

Motif adalah desain yang dibuat dari bagian-bagian bentuk berbagai macam garis/elemen-elemen, yang terkadang begitu kuat dipengaruhi oleh bentuk-bentuk stilisasi alam, benda, dengan gaya dan ciri khas tersendiri (Suhersono, 2004)

Dengan menganalisis motif-motif yang ada pada selendang Koto Gadang, terutama selendang sulam, Selendang dikemukakan oleh Rostamailis dalam (Doni, 2015) bahwa, "Selendang adalah pelengkap busana yang berbentuk empat persegi panjang dengan ukuran tertentu, pemakaian selendang ada yang digantungkan dibahu atau ditutupkan kekepala ada juga yang diselempangkan di bahu kiri dan kanan." Menurut Ida (2009:5)," Sulaman merupakan seni menjahit sebuah aplikasi desain atau pola gambar pada kain atau media lainnya dengan berbagai macam teknik dan badan."

\section{Teori Bentuk dan Struktur}

Menurut Kartika (2004: 30), "Bentuk atau form adalah totalitas dari suatu karya seni. Bentuk juga merupakan satu kesatuan dari unsur-unsur serta komposisi suatu karya. Ada 2 macam bentuk: pertama visual form yaitu bentuk fisik dari suatu karya. Kedua spesial form yaitu bentuk yang tercipta karena adanya hubungan timbal balik antara fenomena dan emosionalnya." Fenomena dan emosional yang tergambar pada bentuk selendang Koto Gadang ini, akibat adanya tuntutan adat istiadat dan keinginan untuk berkarya dan memenuhi kebutuhan masyarakat. Bentuk selendang selalu berkembang sesuai pemintaan pasar bukan lagi kebutuhan adat.

Teori ini juga akan digunakan untuk meneliti bentuk, struktur dari motif dan bentuk selendang. Ditinjau dari segi visual selendang mulai ukurannya dan motif-motif yang ditata pada selendang. Bagaimana ukuran motif 
dan jumlah motif yang akan diterapkan. Hakekat penyusunan atau komposisi senantisa memperhatikan prinsip-prinsip kompsisi, harmoni, kontras, unity, balance, simplicity, dan proporsi. Harmoni yang selaras akan menghasilkan paduan unsur-unsur komposisi yang bagus dalam pencapaian bentuk. Karena komposisi yang bagus akan mengurangi terjadinya kontras yang berlebihan yang mengakibatkan rusaknya komposisi, ramai dan berserakan. Karena masyarakat tradisional sangat menyukai keharmonisan dalam susunan dan struktur (Kartika, 2004: 54). Teori ini untuk meninjau bagaimana komposisi motif, perpaduan warna antara selendang dan warna sulaman sehingga menghasilkan harmoni dan komposisi yang pas.

Jika diperhatikan struktur motif yang diterapkan mempunyai pola tersendiri dan paduan warna yang saling mendukung antara selendang dengan sulaman. Sehingga memiliki keseimbangan yang tidak menimbulkan efek norak atau keramaian. "Struktur motif sangat berpengaruh terhadap keseimbangan bidang yang akan dihias, besar kecilnya motif akan mempengaruhi terhadap penampilan dan keutuhan motif utama (Sundari,2000:111). Teori ini untuk melihat detail dari bagian-bagian motif, pola motif dan ukurannyan.

Kartika (2004:57), "Struktur motif selendang ini mengalami repetisi atau pengulangan unsur-unsur pendukung karya seni”. Motif pada selendang Koto Gadang akan mengalami pengulangan pada ke-empat sudutnya. Teori ini digunakan untuk meninjau pola motif yang diterapkan pada keempat sudut selendang yang mengalami pengulangan dengan ukuran dan bentuk motif yang sama.

Pola motif berdasarkan bentuknya yaitu, motif bentuk lingkaran, motif bentuk hati, bentuk vertikal, bentuk V (Zulkarnaen, 2006:64). teori-teori ini akan digunakan untuk mengungkap masalah pada bentuk dan struktur dari motif sulaman selendang Koto Gadang

\section{METODE PENELITIAN}

Penelitian sulaman Koto Gadang menggunakan metode kualitatif untuk menganalisa data yang diperoleh di lapangan. Metode kualitatif adalah prosedur penelitian yang menghasilkan data deskriptif berupa kata-kata tertulis atau lisan dari orang-orang atau perilaku yang diamati. (Moleong, 2016: 6). Dalam hal ini tidak boleh mengisolasi individu atau organisasi kedalam variabel atau hipotesis, tetapi perlu memandangnya sebagai bagian dari sesuatu keutuhan.

\section{Objek Penelitian}

Objek adalah target penelitian yang dipilih dan menjadi perhatian khusus dalam penelitian. Objek dalam penelitian kali ini adalah karakteristik atau ciri khas pada selendang Koto Gadang dan motif yang diterapkannya. Perbedaan yang menjadikan selendang Koto Gadang berbeda dengan selendang lainnya jika diamati dari segi visualnya.

\section{Populasi dan Sampel}

Populasi dalam penelitian ini adalah seluruh kerajinan selendang Koto Gadang. Sedangkan sampel adalah usaha Kerajinan Amai Setia yang mewakili dari populasi. Penentuan sampel adalah dengan metode purposive sampling. Sampel dipilih karena sangat berpengaruh pada perjalanan sulaman di Koto Gadang. Dengan menghasilkan produk sulaman dengan kualitas baik, dan merupakan pusat pemasaran produk kerajinan bagi masyarakat Koto Gadang. Kerajinan Amai Setia juga pusat kerajinan yang tertua yang didirikan tahun 1911 dan disahkan oleh pemerintah belanda pada tahun 1915 .

\section{Pengumpulan Data}

Data diambil dari hasil data primer dan sekunder. Data primer adalah yang didapat dari survey dan pengamatan lapangan, sedangkan data sekunder adalah yang berasal dari perpustakaan dan referensi dari masyarakat.

\section{1). Studi Pustaka}

Secara garis besar, sumber bacaan itu dapat dibedakan menjadi 2 kelompok yaitu, sumber acuan umum dan sumber acuan khusus. Acuan umum maksudnya penarikan konsep- konsep dan hasil laporan-laporan terdahulu agar informasi yang dibutuhkan lebih relevan. Acuan khusus yang mengarah pada buku jurnal, buletin, tesis, dan lainnya (Suryabrata, 1983:66).

\section{2). Observasi}

Pengamatan langsung yang dilakukan terhadap motifmotif yang diterapkan pada selendang Koto Gadang, diantaranya struktur dan karakter motif dari selendang Koto Gadang. Penelitian dilakukan tempat kerajinan yang sama-sama aktif dalam pengembangan kerajinan sulam di Koto Gadang, serta memiliki pengetahuan tentang sulaman di Koto Gadang. Dengan kriteria beberapa poin yang sudah ditentukan; perencanaan pengamatan, tujuan penelitian, sistematik dalam observasi. 


\section{3). Wawancara}

tahap ini dilakukan dengan memperoleh informasi dari orang-orang yang mempunyai ilmu tentang penelitian kita. Sehingga dapat membantu perolehan data yang valid, dengan mewawancarai ahli sejarah tentang Selendang Koto Gadang, perajin Selendang Koto Gadang, pemilik usaha Kerajinan Amai Setia, tokoh masyarakat dan instansi pemerintahan terkait.

\section{4). Dokumentasi}

Metode ini bisa didapatkan melalui penggunaan alat bantu seperti kamera, dan alat perekam lainnya. Hal ini untuk memperoleh foto-foto dan video.

\section{Analisis Data}

Menurut Miles \& Huberman (1992: 16) analisis terdiri dari tiga alur kegiatan yang terjadi secara bersamaan yaitu: reduksi data, penyajian data, penarikan kesimpulan/verifikasi. Mengenai ketiga alur tersebut secara lebih lengkapnya adalah sebagai berikut:

\section{1). Reduksi Data}

Reduksi data diartikan sebagai proses pemilihan, pemusatan perhatian pada penyederhanaan, pengabstrakan, dan transformasi data kasar yang muncul dari catatan-catatan tertulis di lapangan. Reduksi data berlangsung terus-menerus selama proyek yang berorientasi penelitian kualitatif berlangsung. Antisipasi akan adanya reduksi data sudah tampak waktu penelitiannya memutuskan (seringkal tanpa disadari sepenuhnya) kerangka konseptual wilayah penelitian, permasalahan penelitian, dan pendekatan pengumpulan data mana yang dipilihnya. Selama pengumpulan data berlangsung, terjadilan tahapan reduksi selanjutnya (membuat ringkasan, mengkode, menelusur tema, membuat gugus-gugus, membuat partisi, membuat memo). Reduksi data/transformasi ini berlanjut terus sesudah penelitian lapangan, sampai laporan akhir lengkap tersusun.

Reduksi data merupakan bagian dari analisis. Reduksi data merupakan suatu bentuk analisis yang menajamkan, menggolongkan, mengarahkan, membuang yang tidak perlu, dan mengorganisasi data dengan cara sedemikian rupa hingga kesimpulankesimpulan finalnya dapat ditarik dan diverifikasi. Dengan reduksi data peneliti tidak perlu mengartikannya sebagai kuantifikasi. Data kualitatif dapat disederhanakan dan ditransformasikan dalam aneka macam cara, yakni: melalui seleksi yang ketat, melalui ringkasan atau uraian singkat, menggolongkannya dalam satu pola yang lebih luas, dan sebagainya. Kadangkala dapat juga mengubah data ke dalam angka-angka atau peringkatperingkat, tetapi tindakan ini tidak selalu bijaksana.

\section{2). Penyajian Data}

Miles \& Huberman membatasi suatu penyajian sebagai sekumpulan informasi tersusun yang memberi kemungkinan adanya penarikan kesimpulan dan pengambilan tindakan. Mereka meyakini bahwa penyajian-penyajian yang lebih baik merupakan suatu cara yang utama bagi analisis kualitatif yang valid, yang meliputi: berbagai jenis matrik, grafik, jaringan dan bagan. Semuanya dirancang guna menggabungkan informasi yang tersusun dalam suatu bentuk yang padu dan mudah diraih. Dengan demikian seorang penganalisis dapat melihat apa yang sedang terjadi, dan menentukan apakah menarik kesimpulan yang benar ataukah terus melangkah melakukan analisis yang menurut saran yang dikisahkan oleh penyajian sebagai sesuatu yang mungkin berguna.

\section{3). Menarik Kesimpulan}

penarikan kesimpulan menurut Miles \& Huberman hanyalah sebagian dari satu kegiatan dari konfigurasi yang utuh. Kesimpulan-kesimpulan juga diverifikasi selama penelitian berlangsung. Verifikasi itu mungkin sesingkat pemikiran kembali yang melintas dalam pikiran penganalisis (peneliti) selama ia menulis, suatu tinjauan ulang pada catatan-catatan lapangan, atau mungkin menjadi begitu seksama dan menghabiskan tenaga dengan peninjauan kembali serta tukar pikiran di antara teman sejawat untuk mengembangkan kesepakatan intersubjektif atau juga upaya-upaya yang luas untuk menempatkan salinan suatu temuan dalam seperangkat data yang lain. Singkatnya, makna-makna yang muncul dari data yang lain harus diuji kebenarannya, kekokohannya, dan kecocokannya, yakni yang merupakan validitasnya. Kesimpulan akhir tidak hanya terjadi pada waktu proses pengumpulan data saja, akan tetapi perlu diverifikasi agar benarbenar dapat dipertanggungjawabkan. Miles dan Hubberman (1992: 20) menggambarkan proses analisis data kualitatif sebagai berikut:

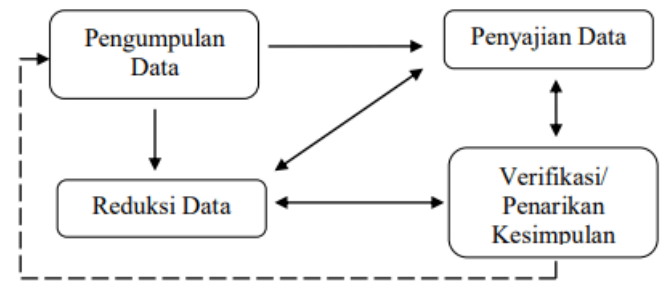

Gambar 1. Proses Analisis Data Kualitatif

Gambar tersebut memperlihatkan sifat interaktif pengumpulan data dengan analisis data, pengumpulan 


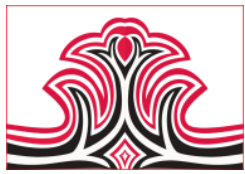

data merupakan bagian integral dari kegiatan analisis data. Reduksi data adalah upaya menyimpulkan data, kemudian memilah-milah data dalam satuan konsep tertentu, kategori tertentu, dan tema tertentu. Hasil reduksi data diolah sedemikian rupa supaya terlihat sosoknya secara lebih utuh. Ia boleh berbentuk sketsa, sinopsis, matriks, dan bentuk lainnya; itu sangat diperlukan untuk memudahkan pemaparan dan penegasan kesimpulan. Prosesnya, tidak sekali jadi, melainkan berinteraksi secara bolak balik. Seberapa kali bolak balik terjadi dalam penelitian? Tentu, sangat tergantung pada kompleksitas permasalahan yang hendak dijawab dan ketajaman daya lacak si peneliti dalam melakukan komparasi ketika proses pengumpulan data. Bagaimana proses analisis data itu dapat dioperasikan? Makalah ini akan berupaya menjawab dan menguraikan.

\section{HASIL DAN PEMBAHASAN}

\section{Hasil}

\section{1). Motif Flora}
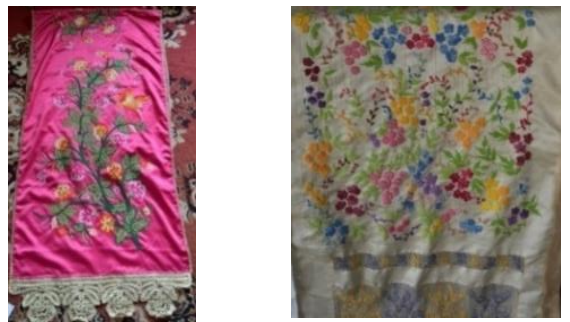

Gambar 2. Motif Bunga Krisan dan Bunga Anggur (Sari, 2020)

\section{2) Motif Fauna}
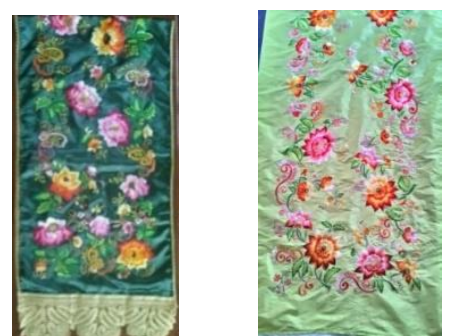

Gambar 3. Motif Burung Kapalo Samek dan Motif Ayam Ayam (Sari, 2020)

\section{3) Struktur Motif}
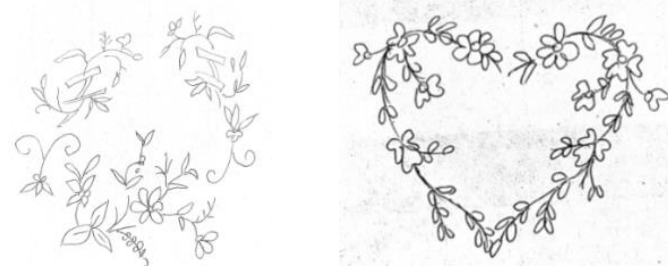

Gambar 4. Struktur Motif Berbentuk

Lingkaran dan Hati

(Sari, 2020)
Gorga : Jurnal Seni Rupa

Volume 10 Nomor 02 Juli-Desember 2021

p-ISSN: 2301-5942 | e-ISSN: 2580-2380

4) Komposisi Motif pada Bidang

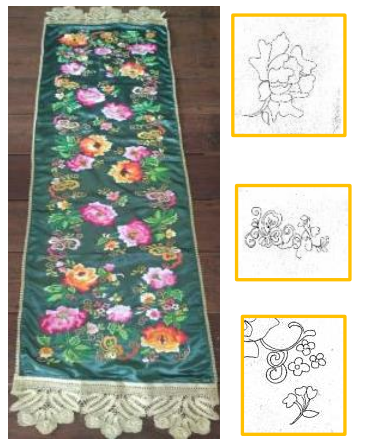

Gambar 5.Motif-Motif Hias Selendang

A. Bungo Gadang B. Suluran (Kaluak Paku) C. Bungo Ketek (Melati) (Sari, 2020)

\section{5). Teknik Sulam Suji Caia}
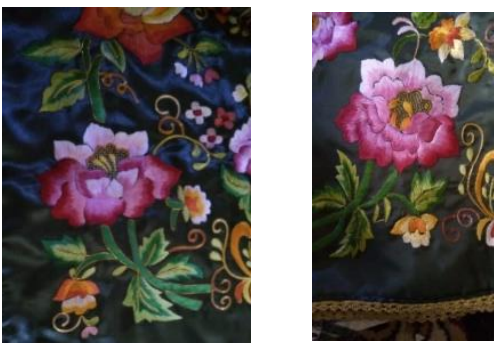

Gambar 6. Teknik Sulam Suji Caia (Sari, 2020)

\section{6). Teknik Sulam Kapalo Samek}

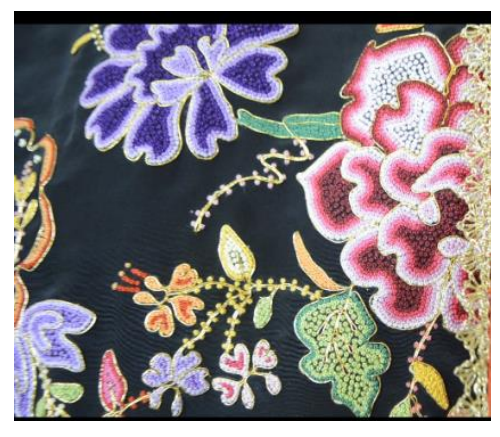

Gambar 7. Teknik Sulam Kapalo Samek (Sari, 2020)

\section{Pembahasan}

Selendang Koto Gadang dianggap sebagai warisan pusaka oleh masyarakatnya, melengkapi segala kegiatan adat dan tradisi di masyarakat mulai dari kelahiran hingga kematian. Perjuangan tokoh- tokoh penggiat sulaman dari Koto Gadang sering mendapat hambatan, karena adanya aturan tidak tertulis bahwa "Yang mewarisi kerajinan ini hanyalah anak nagari Koto Gadang". Sehingga inilah yang membuat sedikitnya perajin yang mampu membuat selendang Koto Gadang. Faktor ini juga yang menjadikan selendang sulam Koto Gadang berbeda, karena teknik pembuatan hanya diketahui oleh orang Koto Gadang. Karakter atau ciri khas selendang dapat dilihat dari 
bentuk, sulaman dan motif yang ada pada selendang. Selendang sulam dalam masyarakat Koto Gadang memiliki kedudukan yang penting, selendang bukan sekedar sehelai kain yang disulam indah dengan benang dan dipakai oleh wanita dalam berbagai kegiatan, tetapi sehelai selendang dapat dijadikan saksi perjalanan budaya Minangkabau. (Garang, 2019:17). Bisa dilihat dari berbagai kebudayaan yang mempengaruhi motif dan sulaman yang berkembang di Minangkabau terutama Koto Gadang. Beberapa kebudayaan yang mempengaruhi nya adalah Cina, Eropa. Kegiatan sulam-menyulaman di Koto Gadang sudah berkembang semenjak kerajaan Pagaruyuang. Menurut sejarah yang berkembang dikalangan masyarakat.

Kegiatan menyulam diajarkan oleh seorang putri kerajaan aceh anak dari Ali Mughayatsyah, yang bersuamikan Raja Ibadat dari Sumpur Kudus. Putri Lambeuja melarikan diri dari Sumpur Kudus dengan ketiga orang anaknya, karena kecewa kepada Raja Ibadat. Putri mengikuti rombongan ke Koto Gadang, dan disana dia memulai kehidupan baru. Pada tahun 1511 setelah mengirimkan surat kepada ayahnya tentang apa yang terjadi, ia mulai mengajarkan kegiatan sulam- menyulam di Koto Gadang dan Sianok. Mamangan yang terkenal di Minangkabau, tanti nan dari lambeuja, tukang Sianok jo Koto Gadang( tanti kain atau sulam dari putri lambeuja dibuat oleh anak gadis Sianok dan Koto Gadang. Namun hanya nagari Koto Gadang yang berminat meneruskan dan melestarikan sulaman hingga sekarang. Berdirinya Amai Setia membuktikan tingginya minat masyarakat dan mempelajari dan mempertahankan tradisi menyulam di Koto Gadang (canang,1994). Putri dari kerajaan Aceh mengajarkan cara menyulam selendang dengan teknik kerawang kepada masyarakat Koto Gadang dan sekitarnya. Sedangkan suji caie diperkenalkan oleh orang Cina pada masa perdagangannya, hal ini bisa kita amati dari warna-warna cerah yang diterapkan padaa Suji Caie. Sedangkan rendo bangku berasal dari Belgia atau daerah-daerah Eropa lainnya (Wawancara dengan Fitri Haryanti pada hari Kamis,30 April 2020 di Koto Gadang).

\section{1). Bentuk motif}

Bentuk Motif hias pada Selendang Khas Koto Gadang antara lain:

\section{(1). Motif Fauna}

pada selendang sulam Koto Gadang juga terdapat beberapa motif hewan, diantaranya kupu-kupu, burung, kumbang. Motif ini jarang digunakan pada teknik suji caie, motif ini sering diterapkan dengan teknik kepala peniti dan suji terawang. Penerapan motif ini sering dipasangkan dengan bunga, dan motif hewan sebagai pelengkapnya. Contohnya motif yang terdapat pada selendang tradisional. Motif yang diterapkan tersebut sudah digunakan pengrajin semenjak tahun 1970-an dan sampai sekarang ada beberapa jenis motif yang mengalami perkembangan bentuk dari bentuk awalnya. Hal ini terjadi pada motif pada sulaman kapalo samek tahun 1970-an yang memiliki perbedaan bentuk dengan motif burung pada sulaman kapalo samek tahun 2000an.
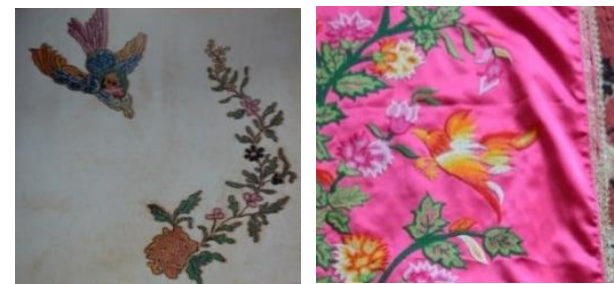

Gambar 8. Perbedaan Bentuk Motif Tahun 1970-An Dan Motif Tahun 2000-an (Sari, 2020)

\section{(2). Motif Flora}

Bentuk motif selendang Koto Gadang pada umumnya berbentuk flora. Motif flora meliputi bunga mawar, dahlia, krisan, melati, sedangkan motif flora, kupukupu, burung. Motif flora yang paling sering diterapkan pada dengan teknik suji caie dan kapalo samek.

\section{2). Struktur Motif Selendang}

Motif selendang Koto Gadang memiliki beberapa bentuk pola saat diaplikasikan pada selendang. Bentuk pola ini sangat sering digunakan pada selendang ringan, karena selendang ringan hanya memerlukan sedikit motif saja. Motif dengan pola sering digunakan pada selendang dengan motif tabur, dan bunga-bunga kecil. Menurut Zulkarnaen (2006: 64) motif sulaman berdasarkan bentuknya dibedan atas:

\section{(1). Bentuk Lingkaran}

Motif berbentuk lingkaran ditemukan pada beberapa motif sulaman. Motif dengan pola berbentuk lingkaran in banyak digunakan untuk bagian tengah selendang dan diselang selingi dengan isen berbentuk daun.

\section{(2). Motif Berbentuk Hati}

motif berbentuk hati juga ditemukan pada beberapa selndang seperti selendang ringan. Bentuk motif hati yang digambarkan Zulkarnaen sesuai dengan pola hati yang diterapkan oleh perajin Koto Gadang, susunan 
dan letak motif bunga juga sesuai. Jumlah bunga dan suluran juga seimbang.

Bentuk vertikal pada selendang Koto Gadang Memiliki kesamaan, ukuran dan susunan motif bunga juga sama. Susunan bentuk motif seperti ini biasanya digunakan pada selendang ringan, atau selendang untuk acara adat biasa.Bentuk motif yang disajikan merupakan beberapa motif yang dipengaruhi oleh kebudayaan Belanda atau Eropa, bisa dilihat dari pemilihan warna sulaman dan ukuran motif bunga yang kecil-kecil. Motif ini sering digunakan pada tahun 90-an, karena masa itu Belanda bermukim di Koto Gadang dan sekitarnya.

\section{3). Komposisi Motif Pada Selendang}

struktur motif pada selendang sulam memiliki aturan serta tata susunannya. Sulaman corak senada sering juga disebut untuk selendang sulam Koto Gadang. Senada, harmonis, balance menyatu dengan selendang, rendo atau jambulnya. Pemilihan gradasi warna yang tepat akan menambah keindahan selendang.

\section{(1). Kesatuan}

Kesatuan Merupakan efek dari susunan atau komposisi diantara hubungan unsur pendukung karya (Kartika, 2004: 56). Dalam sususunan motif pada selendang Koto Gadang terdiri dari beberapa unsur pendukung, diantaranya motif utama, dan dan motif pendukung. Bungo gadang sebagai motif utama dan titik fokus desain, tetap membutuhkan motif bungo ketek dan sulur sebagai penguat dan kesatuan komposisi. Hal ini juga merupakan kemahiran perajin Koto Gadang dalam kemampuan memadukan komposisi yang utuh, agar tidak terlihat sederhana dan serasi.

\section{(2). Keseimbangan}

Keseimbangan jika dilihat dari segi bentuk ada 2 yaitu formal balance dan informal balance. Dalam desain selendang Koto Gadang identik dengan formal balance. Dan sudah menjadi ciri khas tersendiri bagi selendang Koto Gadang. Keseimbangan komposisi motif bagian atas dan bawah, kiri dan kanan akan membuat tampilan selendang semakin menarik.

\section{(3). Kesederhaan Teknik}

Teknik yang digunakan untuk mencapai hasil yang dikendaki tidak harus dengan teknologi modern dan canggih. Meskipun menyulam secara manual dan tradisional, kehalusan dan kerapian perajin Koto Gadang tidak bisa di pungkiri. Menurut mereka kemampuan menyulam yang bagus selain menggunakan teknik sisip juga karena pengerjaan yang berulang- ulang, yang sudah mereka tekuni secara turun menurun. Dengan teknik sederhana bisa menghasilkan karya dengan hasil dan kualitas baik. Dua teknik yang menjadi ciri khas Koto Gadang teknik suji caie dan kapalo samek.

Sulaman suji caie memiliki ciri khas dengan menggunakan teknik sisip bukan buhul. Mulai dari awal menyulam dan mengakhiri sulaman sisa sulaman akan disisipkan di sela- sela benang sulaman. Teknik ini merupakan salah satu faktor kenapa sulaman Koto Gadang itu terlihat rapi, halus dan bidang sulaman depan kebelakangnya sama.

Teknik ini dilakukan dengan cara menjahitkan benang secara panjang dan pendek pada pola yang sudah gambarkan dengan menggunakan gradasi warna. Turunan warna bisa mencapai 5-6 warna, sehingga warna bisa mencair atau menyatu antara satu dan lainnya. Teknik ini juga mendukung terciptanya karakter atau ciri khas dari moti Koto Gadang, karena warna dan efek tiga dimensi menjadikan motif lebih terfokuskan.

Teknik ini dilakukan dengan cara menjahitkan benang secara panjang dan pendek pada pola yang sudah gambarkan dengan menggunakan gradasi warna. Turunan warna bisa mencapai 5-6 warna, sehingga warna bisa mencair atau menyatu antara satu dan lainnya. Teknik ini juga mendukung terciptanya karakter atau ciri khas dari moti Koto Gadang, karena warna dan efek tiga dimensi menjadikan motif lebih terfokuskan.

Teknik kepalo samek di Koto Gadang ada dua macam, kepalo samek buka dan kapalo samek tutup. Kepalo samek buka karena penggulungan benang hanya sekali pada jarum, sedangkan kapalo samek tutup penggulungan benang dua kali. Teknik ini biasanya menggunakan tiga turunan warna saja, teknik ini juga mengahasilkan efek yang berbeda pada motif. Jika pada teknik suji motif akan terlihat lebih simpel, karena akan mencairkan benang sehingga membutuhkan garis motif yang sulit dan lebih detail, karena teknik ini mengikuti garis motif dan baru mengisi bidang bunga.

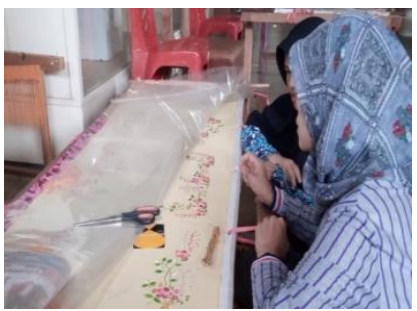

Gambar 9. Manjilik ( Menjahitkan Benang Emas) (Sari, 2020)

Teknik yang digunakan untuk memperindah motif dengan menjahitkan benang emas atau makau pada 


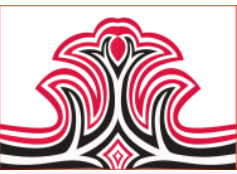

pinggiran motif. Dengan cara menempelkan benang emas pada garis motif kemudian dijilid atau di rekatkan dengan benang katun dengan cara jelujur. Pada teknik suji caia, motif yang diberi benang emas hanya bagian batang dan daun saja. Teknik ini biasanya diterapkan pada selendang gadang atau kebesaran yang akan digunakan untuk pesta. Pada teknik kapalo samek seluruh bagian motif akan dipasang benang emas.

Aksentuasi dikenal juga dengan istilah pusat perhatian atau center of interest. Beberapa hal yang bisa dijadikan pusat perhatian pada selendang Koto Gadang yaitu pada pengulangan, warna, dan ukuran motif. Pada selendang Koto Gadang motif bungo gadang dijadikan pusat yang menarik perhatian. Ukuran motif ini lebih besar dari motif lainnya, warna yang digunakan juga mencolok karena penggunaan turunan warna hingga 6 turunan warna. Meskipun mencolok warna dari motif tidak menimbulkan efek norak. Pengulangan motif besar yang ditabur pada selendang menjadikan motif bungo gadang lebih mencolok.

\section{Karakteristik Bentuk Motif Selendang Sulam Koto Gadang}

Karakter atau ciri khas yang ada pada selendang Koto Gadang dapat dilihat dari segi visualnya. Menurut Juwita (2019) mengatakan:

Karakter adalah suatu yang khas yang terdapat pada objek, warsono dalam Rahmadona mengungkapkan karakteristik tidak lepas dari budaya, budaya sebagai kumpulan nilai dan norma di bentuk dan disepakati oleh masyarakat sehingga menjadi suatu ciri khas.

Selendang Koto Gadang dianggap sebagai warisan pusaka oleh masyarakatnya, melengkapi segala kegiatan adat dan tradisi di masyarakat mulai dari kelahiran hingga kematian.

Perjuangan tokoh- tokoh penggiat sulaman dari Koto Gadang sering mendapat hambatan, karena adanya aturan tidak tertulis bahwa "Yang mewarisi kerajinan ini hanyalah anak nagari Koto Gadang". Sehingga inilah yang membuat sedikitnya perajin yang mampu membuat selendang Koto Gadang. Faktor ini juga yang menjadikan selendang sulam Koto Gadang berbeda, karena teknik pembuatan hanya diketahui oleh orang Koto Gadang. Karakter atau ciri khas selendang dapat dilihat dari bentuk, sulaman dan hiasan yang ada pada selendang.

\section{1). Motif Bunga Peony (Botan)}

Motif bunga yang sering digunakan pada selendang Koto Gadang yaitu bunga peony (Paeonia Lactiflora). Bunga ini merupakan salah satu bunga Nasional dari Tiongkok, bunga ini sering gunakan untuk upacara
Gorga : Jurnal Seni Rupa

Volume 10 Nomor 02 Juli-Desember 2021

p-ISSN: 2301-5942 | e-ISSN: 2580-2380

pernikahan karena memiliki makna mengenai cinta, kebahagiaan serta lambang kehormatan. Warna bunga biasanya bewarna merah, merah tua, putih, merah jambu, kuning, dan ungu.

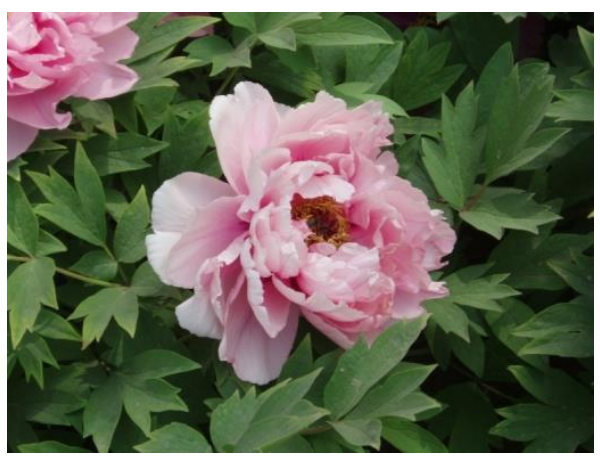

Gambar 10. Bentuk Bunga Peony (Botan) yang Dijadikan Motif Pada Selendang (Sari, 2020)

Bunga Peony atau Botan merupakan motif khas selendang Koto Gadang, karena Nareh dan Lubuk Basung memiliki motif berbeda, terutama motif bunga Botan yang ada pada selendang Koto Gadang (Riza Mutia, 2020).

Kuatnya pengaruh kebudayaan Cina menjadi alasan kenapa bunga ini bisa diterapkan pada Selendang gadang yang sering digunakan pada acara pernikahan. Meskipun belum ada pematenan motif oleh perajinKoto Gadang, tapi secara umum sudah diakui oleh berbagai daerah terutama kepengurusan Museum Adityawarman Padang melihat dari segi perkembangan sejarahnya.

Motif Bunga peony berkembang pada tahun 1970-an, dibuat dengan teknik sulam kapalo samek. Motif dibuat lebih detail namun warna yang digunakan tidak terlalu kontras dengan warna selendang. Motif bunga kecil dan suluran juga lebih simpel. 

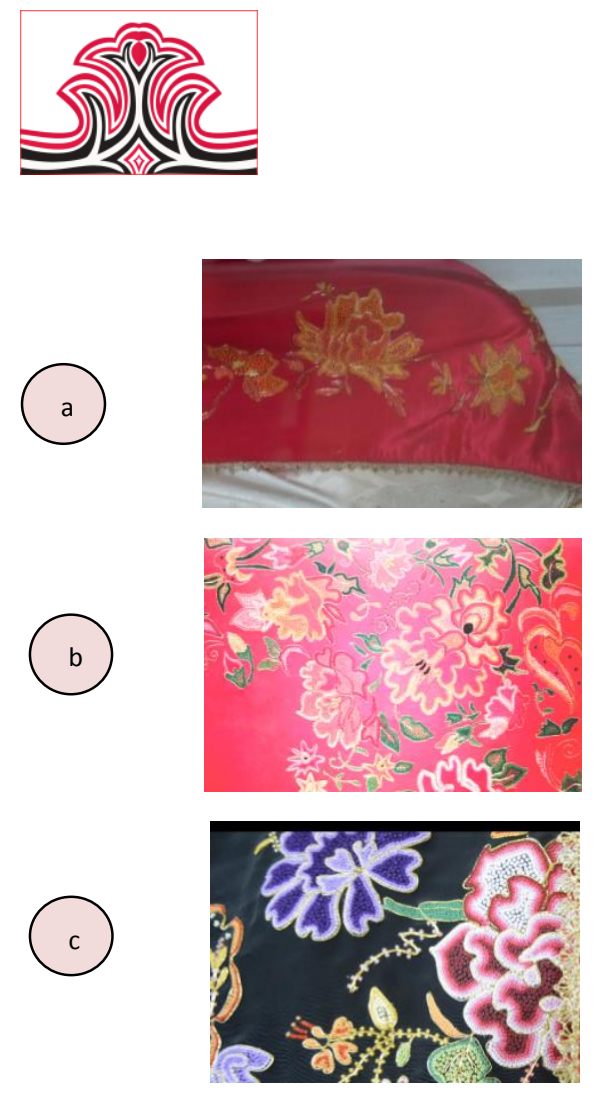

Gambar 10. Perkembangan Bentuk Motif Bunga Peony A) Tahun 1970-An, B) Tahun 1990-An Dan

C ).Tahun 2000-An

(Sari, 2020)

\section{2). Motif Bunga Krisan}

Bunga krisan atau chrysanthemum juga merupakan motif yang sering digunakan pada selendang Koto Gadang. Mempunyai makna yang sama dengan bunga Botan, bermakna tentang cinta, kasih sayang dan ungkapan kagum. Pemberian bunga krisan di Tiongkok mempunyai makna dari jumlahnya. Jika bunga yang diberikan 6-10 tangkai berarti tanda cinta, di Koto Gadang penggunaan jumlah bunga dimaknai dengan umur si pemakai selendang dan status. Meskipun berbeda makna namun tetap menyimbolkan sesuatu sebagai pemberitahuan atau sinyal tertentu.

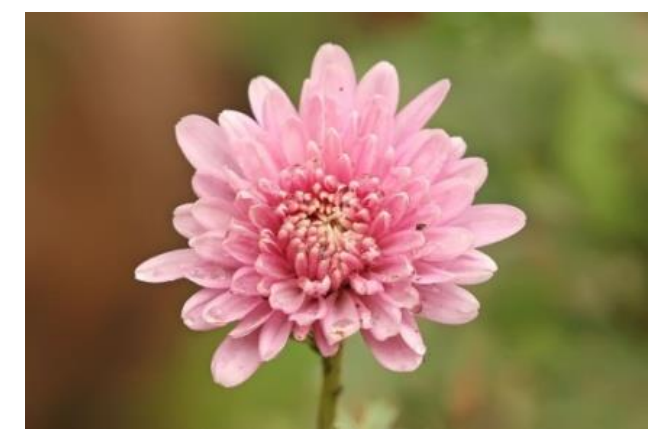

Gambar 11. Bunga Krisan Yang Dijadikan Motif Pada Selendang (Sari, 2020)

Bunga Krisan sering diterapkan pada selendang gadang dalam bentuk desain batangan. Berbeda dengan motif bunga Botan yang diterapkan dengan suluran dan pada sudut-sudut selendang, bunga Krisan lebih sering
Gorga : Jurnal Seni Rupa

Volume 10 Nomor 02 Juli-Desember 2021

p-ISSN: 2301-5942 | e-ISSN: 2580-2380

terapkan dengan batang dan rantingnya. Masyarakat Tiongkok memaknai pemberian bunga krisan dengan menghitung jumlah bunga yang diterima. Warna bunga Krisan yang diberikan juga memberi makna yang berbeda. Filosifi masyarakat Tiongkok menyatakan"Kalau anda ingin bahagia seumur hidup tanamlah Bunga Krisan.”(Swantika, 2018).

Filosofi ini jugalah yang menjadi tujuan diterapkannya motif Bunga Krisan, karena selendang gadang digunakan pada hari pernikahan yang secara tidak langsung sudah menjadi simbol ucapan kebahagian kepada sipengantin, atau sebalikanya. Motif Bunga Krisan pada selendang gadang sering diterapkan pada selendang pengantin atau wanita yang baru menikah, karena biasanya bunga besar yang diterapkan lebih dari delapan bunga bahkan lebih. Warna selendang yang diterapkan juga warna cerah, warna tersebut sampai sekarang masih diterapkan oleh masyarakat Koto Gadang, tetapi dengan makna yang sudah berbeda berbeda.

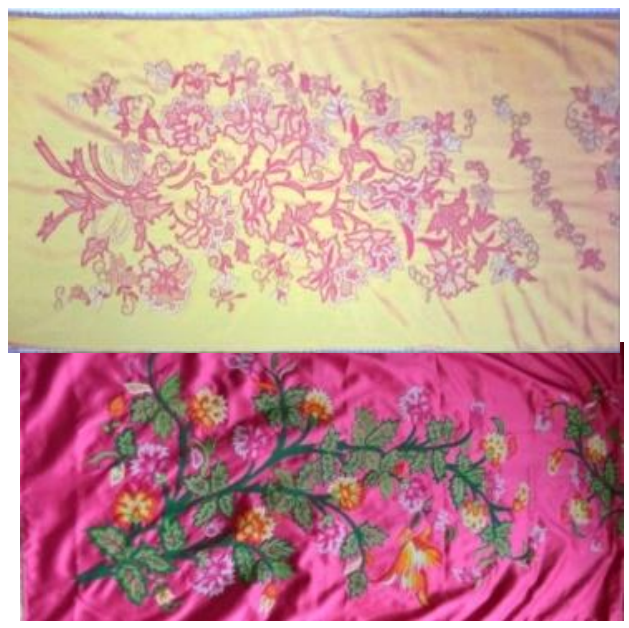

Gambar 12. Perkembangan Bentuk Motif Bunga Krisan A)Tahun 1990-an, B) Tahun 2000-An (Sari, 2020)

Dari bentuk motif tidak memiliki banyak perubahan, namun ukuran bunga dan warna mengalami perubahan. Hal ini disebabkan oleh permintaan konsumen yang terus berkembang mengikuti mode, bahkan kehilangan makna dari fungsi motif yang diterapkan pada selendang.

Kolektor yang biasanya mengkoleksi selendang Koto Gadang juga sering membeli sesuai selera mereka. Warna lembut terutama warna ungu paling sering dibeli oleh Ibu Mufida Jusuf Kalla asalkan pola berbeda dan tetap menggunakan motif Koto Gadang yang merupakan ciri khas (Haryanti, 2020: 23). 


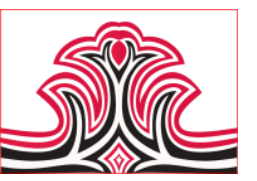

Daerah diluar Koto Gadang juga menggunakan selendang Koto Gadang dalam upacara adatnya, namun tidak memakai aturan adat di Koto Gadang. Kami sebagai Pasumandan wajib menggunakan selendang sulam Koto Gadang atau selendang bajaik, dalam acara pernikahan. Motif sedikit atau banyaknya itu tidak penting, yang terpenting menggunakan selendang sulam dari Koto Gadang (Refrida, 2020 ).

\section{3). Struktur motif pada selendang}

Pada selendang Koto Gadang selain dari motif dan pola, ciri khas juga terlihat pada struktur motif atau susunan motif pada selendang. Struktur juga salah satu ciri khas dan pembeda dengan selendang daerah lainnya.Perajin menyusun motif dari bunga kecil ke bunga besar sebagai bentuk pertumbuhan bunga dari putik ke bunga yang mekar.
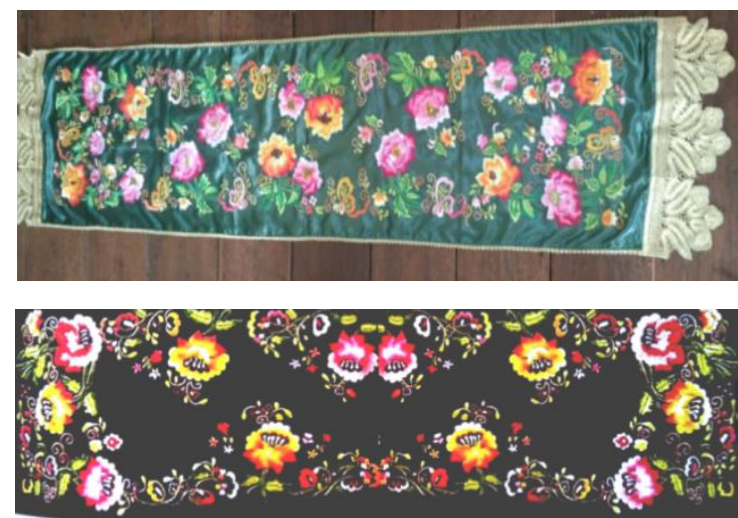

Gambar 13. Perbandingan Visual, A. Selendang Suji Caie Koto Gadang, B. Selendang Suji Caie Canduang (Sari, 2020)

Jika diperhatikan struktur motif pada selendang Koto Gadang berbeda dengan selendang daerah lainnya. Penempatan motif pada selendang Koto Gadang seimbang namun tidak sama sudut kiri dan kanan, serta pada bagian selendang lainnya. Sedangkan pada selendang sulam Canduang, struktur motif kedua sisi selendang sama, terlihat seperti cermin. Alasan perajinKoto Gadang memilih pola seperti ini agar motif bunga yang disusun akan saling berhadapan pada bagian tengah selendang, sehingga motif selendang seirama atau senada.

\section{4). Struktur Motif pada Selendang}

Dalam seni rupa ada beberapa peranan warna, diantaranya warna sebagai warna, warna sebagai elemen, warna sebagai representasi alam, warna sebagai lambang atau simbol. Bagi masyarakat Koto Gadang, warna berperan sebagai simbol atau tanda. Warna sebagai simbol untuk melambangkan sesuatu yang merupakan tradisi atau pola umum. Demikian juga merupakan lambang tertentu yang dipakai di dalam karya seni yang menggunakan pola tertentu
Gorga : Jurnal Seni Rupa

Volume 10 Nomor 02 Juli-Desember 2021 p-ISSN: 2301-5942 | e-ISSN: 2580-2380

seperti pada: logo, badge, batik, wayang, dan pada busana tradisi misalnya warna merah dapat berarti pengambaran rasa marah, gairah cinta yang membara, bahaya, berani, dan lain-lainnya (Kartika, 2004: 50). Bagi masyarakat Koto Gadang, wanita yang baru menikah akan menggunakan selendang dengan warna terang seperti, merah, merah jambu, merah hati, kuning. Warna ini melambangkan keceriaan karena pemakai masih muda dan baru menikah. Sedangkan wanita dengan umur lebih tua atau yang sudah memiliki cucu akan menggunakan selendang dengan warna yang lebih gelap, seperti hijau, biru. Penggunaan Warna sebagai acuan merupakan salah satu ciri khas atau karakter selendang Koto Gadang.

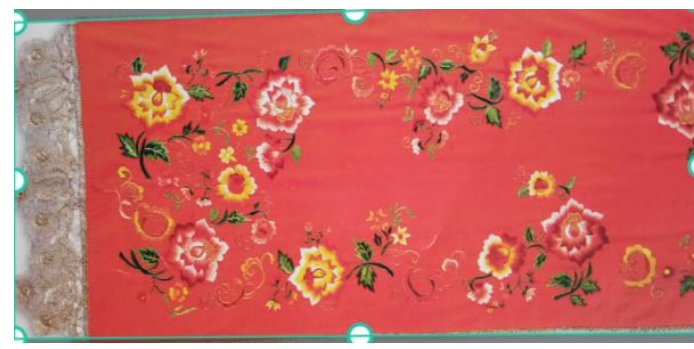

Gambar 14. Selendang Kebesaran dengan Warna Khas (Sari, 2020)

Selendang kebesaran pada foto diatas, motif besar lebih banyak aplikasikan. Motif bunga besar bisa mencapai 12 bunga kedua sisi, ini menandakan bahwa pengguna pengantin baru atau baru menikah. Selain warna merah ada warna kuning atau warna cerah lainnya. Perkembangan mode atau gaya menjadikan banyaknya pergeseran kebudayaan lokal atau tradisi, karena banyak masyarakat tertuntut oleh kebutuhan ekonomi. Namun sebagian perajindan tokoh- tokoh masyarakat masih berusaha menjaga adat-istiadat mereka dengan pengenalan dan pelatihan sulaman pada tingkat sekolah dasar di Koto Gadang.

\section{KESIMPULAN DAN SARAN}

\section{Kesimpulan}

Bentuk dan struktur motif selendang Koto Gadang terlihat dari segi susunan motif, para perajin selalu mendahului bunga dari yang kecil ke motif yang besar. Posisi motif Bunga yang besar akan selalu berada di tengah selendang, karena merupakan bagian utama atau fokus dari selendang itu sendiri. Bentuk motif selendang juga berbeda dari motif terdahulu yang lebih sederhana karena pengaruh kebudayaan Belanda dan itu biasa digunakan pada selendang ringan. Sedangkan motif yang lebih ramai pengaruh kebudayaan Cina dan biasa digunakan pada selendang gadang (kebesaran), yang dihiasi rendo bangku dari benang emas, atau makau. Karena pada umumnya motif yang digunakan bukanlah jenis bunga yang khas atau banyak tumbuh 


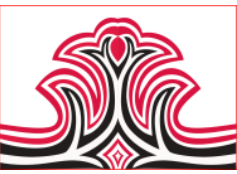

di Indonesia, namun bunga yang mempunyai makna penting di negara-negara eropa dan Tiongkok China.

Ciri khas motif selendang terdapat pada motif floranya, yaitu bunga Botan dan Krisan, karena makna bunga Botan sebagai ungkapan pada pasangan penganten dan jumlah bunga pada bunga Krisan yang bermakna ungkapan pada selendang yang digunakan sebagai simbol status seorang wanita. Ukuran motif yang besar berbeda sehingga susunan motif menjadi ciri khas. Pola atau struktur motif pada selendang berbeda dari daerah lain yang biasa menggungakan struktur formal mirror, sedangkan selendang Koto Gadang menggunakan susunan diagonal.

Beberapa tahun belakangan ini motif selendang mengalami perputaran zaman, di mana motif simpel kembali diminati oleh konsumen. Motif bunga besar dan warna terang sudah dianggap kuno dan terlalu ramai, karena konsumen sudah mengikuti selera mode yang sederhana dan warna yang lembut.

\section{Saran}

Dalam menghadapi perkembangan zaman dan sulitnya perekonomian, akan membawa beberapa faktor perubahan terhadap masyarakat berbudaya. Mereka akan merasa bingung dalam menlestarikan dengan tradisi yang ada, atau melestarikan dengan memenuhi ekomi. Salah satunya banyak yang meninggalkan aturan-aturan dalam pembuatan, penataan warna dan motif pada selendang. Hal ini perlu menjadi perhatian bagi masyarakat atau perajin, meskipun dalam memenuhi perekonomian sangat penting. Tradisi adat istiadat tetap sangat penting karena merupakan jati diri daerah itu sendiri, dengan melakukan bimbingan dan edukasi bagi generasimuda daerah itu sendiri.

\section{DAFTAR RUJUKAN}

Canang. (1994). Tabloid Koto Gadang. Koto Gadang:

Garang, DT. (2019). Ragam hias Minangkabau. Padang: Pemprov Sumbar.

Garang, DT. (2019). Sulam Bordir Sumatera Barat. Padang: Pemprov Sumbar.

Ida, Y. (2009). No Titlepaduan Lengkap Sulam (Cetakan 1). Surabaya: Tiara Aksa.

Juwita, N. (2019). Karakteristik Dan Makna Simbolik Masjid Muhammad Cheng Hoo. Makassar: Doctoral dissertation, Universitas Negeri Makassar.

Kartika, D. S. (2004). Seni Rupa Modern (Cetakan 1). Bandung: Rekayasa Sains.

Miles, Mattew B. dan A. Michael Huberman. (1992). Qualitative Data Analysis: A Sourcebook of New Method. Terjemahan Tjetjep Rohendi Rohidi.
Gorga : Jurnal Seni Rupa

Volume 10 Nomor 02 Juli-Desember 2021 p-ISSN: 2301-5942 | e-ISSN: 2580-2380

Analisis Data Kualitatif: Buku Sumber tentang Metode-metode Baru. Jakarta: Penerbit Universitas Indonesia (UI-PRESS).

Moleong, Lexy J. (2016). Metodologi Penelitian Kualitatif: Edisi Revisi. Bandung: Remaja Rosda Karya.

Rahman, D., Efi, A., \& Novrita, S. Z. (2015). Ragam Hias Suji Cair pada Sulaman Selendang Kotogadang Kabupaten Agam Sumatera Barat (Studi Kasus di Yayasan Amai Setia). E-Journal Home Economic and Tourism, 9(2),

Sari, Yuni Kartika. (2020). " Motif Sulaman Selendang". Hasil Dokumentasi Pribadi: 10 Januari 2020, Koto Gadang.

Sita, R. D., \& Mity J. Juni. (2011). Sulam, Tenun, dan Renda Khas Koto Gadang. Jakarta: Dian Rakyat.

Sugiyono. (2008). Metode Penelitian Kuantitatif Kualitatif Dan $R \& D$. Bandung: Alfabeta.

Suhersono, H. (2004). Desain Bordir Inspirasi Motif Bordir Cina. Jakarta: PT.Gramedia Pustaka Utama.

Sundari, Sri. (2000). Seni Ukir Pandai Sikek Dalam Masyarakat Minangkabau Yang Berubah. Yogyakarta: Tesis UGM.

Suryabrata, S. (1983). Metodologi Penelitian. Jakarta: Grafindo Persada.

Swastantika, Dyah. (2018). Bunga Krisan:Manfaat, Cara, Menanam, dan Perawatannya. https://www.homify.co.id/ideabooks. (diakses 01 Agustus 2020).

Zulkarnaen, Y. (2006). Sulam Benang Motif Bunga (Pertama). Jakarta: Puspa Swara. 